\title{
The concept organic in foods: a case study in the Azapa Valley, Chile
}

\author{
Concepto y consumo de alimentos orgánicos: un estudio de caso \\ en el valle de Azapa, Chile
}

\author{
Falon Sweeney ${ }^{1}$, Felipe Salinas Vásquez ${ }^{2}$, Germán Sepúlveda Chavera ${ }^{2}$
}

\begin{abstract}
To identify the level of knowledge, understanding, and consumption of organic food products in the North of Chile, a case study was performed with a group of patients of the Rural Health Post located in San Miguel de Azapa, Arica \& Parinacota, Chile. Opinions of the nutritionist employed at the health post and a local organic farmer are included in the analysis of this study. The patients' interpretation and understanding of the definition of an organic food product was explored in this descriptive, transversal and ethnographic study. The subjects were males and females ages 18 and older of different ethnicities and levels of education. The information gathered reveals that a distorted and poorly defined idea of organic food products exists in Azapa Valley, independent of age, ethnic and/or education level parameters. No individual correctly defined what signifies an organic food product, with the exception of the local organic farmer. It is necessary to establish a campaign to produce an understanding of the definition of an organic food product, as well as the advantages and benefits that the production and consumption of organic food products would have on the land and people of northern Chile.
\end{abstract}

Key words: organic, nutrition, ethnicity, rural

\section{RESUMEN}

Para identificar el nivel de conocimiento, percepción y consumo de alimentos orgánicos en el extremo norte de Chile se hizo un estudio de caso basado en un grupo de personas usuarias de la Posta de Salud Rural San Miguel de Azapa, XV Región de Arica y Parinacota. Se incorporó la opinión del nutricionista del sistema de salud rural y de un agricultor orgánico de la localidad. Se exploró la percepción de las personas acerca de la definición de un producto orgánico por medio de un estudio descriptivo, transversal y etnográfico. Se trabajó con personas de diferente edad, sexo, etnia, nivel de educación. La información disponible permite concluir que existe una visión distorsionada y poco definida del concepto orgánico, independiente de los parámetros de edad, etnia y nivel de educación. Ningún individuo definió claramente lo que significa que un producto sea orgánico, excepto el agricultor orgánico de la localidad. Es necesario establecer un programa de difusión del conocimiento y de las ventajas y beneficios que tiene la producción y consumo de productos orgánicos en el extremo norte de Chile.

Palabras clave: orgánico, nutrición, etnia, rural.

\section{Introduction}

The agriculture and livestock industry in Chile accounts for $8.8 \%$ of the country's Gross Domestic Product (GDP) and is the second largest export, representing $25 \%$ of its economy and employing more than 1 million people. It is estimated that by 2030 this economic sector will account for more than $1 / 3$ of the Chilean economy (Jensen, 2012). Undoubtedly, the agriculture and livestock industry is essential for the country's economic wellbeing.
For the past few decades the Chilean agricultural industry has put emphasis on its exports more than its domestic demand, due to the profitability of the global market.

In the agricultural field, Region XV (Arica \& Parinacota) has an ideal climate for cultivation throughout the entire year; it is the main supplier of agricultural products for the rest of the country during the winter (Saavedra and Tapia, 2009). The costal desert climate boasts sufficient cloud cover, moderate winds, high relative humidity, high direct

\footnotetext{
1 The George Washington University, 2121 Eye Street, NW, Washington, D.C., 20037.

2 Universidad de Tarapacá. Avda. General Velásquez 1775, Arica-Chile, gsepulve@uta.cl

* Corresponding author:
} 
solar radiation and absence of frost throughout the entire year. The average annual temperature is $18{ }^{\circ} \mathrm{C}$, with maximum annual averages of $23.6^{\circ} \mathrm{C}$ and minimum annual averages of $13.8^{\circ} \mathrm{C}$ (Torres and Acevedo, 2008).

Globally there is a strong demand for organic food products, due to the increasing awareness of food production processes and their effects on human health. Despite the growing global demand for organic food products, Chile represents only $0.02 \%$ of the global organic farm area (Kilcher and Willer, 2012). It is estimated that Chile has only 151,000 organic hectares, which account for only $0.05 \%$ of the country's agricultural land area, however this production is predominately for exportation, not domestic consumption (ODEPA, 2011). Considering these figures, this study explored the level of knowledge and understanding of the organic products among the people of Azapa Valley, Arica, Chile.

\section{Methods}

The study was conducted in Azapa Valley (XV Region, Arica and Parinacota), Chile in the Rural Health Post (RHP), San Miguel de Azapa, and on an organic farm, between May and June of 2014. During the first week background information was collected, primary and secondary sources were references, and relationships were formed with professors at The University of Tarapacá and with patients of the Rural Health Post of San Miguel de Azapa. Additionally, the investigator visited various local organic farms in Arica. The purpose of this study was to estimate the community's understanding and perception of organic food products. The second week was dedicated to field study. The final two weeks were dedicated to data analysis and presentation.

\section{Study design}

This study was descriptive, transversal, and ethnographic with qualitative information. It was conducted during one month in a specific geographic location.

\section{Place, population, and sample of the study}

The population under analysis corresponded to people who consume food produced in Azapa
Valley (acquired in the local market, "El Agro"); it also incorporated an interview with the nutritionist working at the RHP San Miguel de Azapa and an interview of an organic olive farmer. The sample was random and considered that the food the inhabitants of Azapa Valley (and the rest of Arica) consume was produced locally. It was also assumed that, because of their geographic location, the inhabitants of Azapa Valley would have had the best access to organic food products of all Arica's citizens. The sample was non-probabilistic and included patients over 18 years of age who received healthcare from the RHP San Miguel of Azapa, both male and female. The interview of the nutritionist and the surveys took place in the RHP, and the interview of the organic farmer took place on his farm, located in Azapa Valley.

\section{Data collection}

A questionnaire was created to collect information from the consumers. To understand the opinions of key actors (farmer, nutritionist), structured interviews were conducted. The questionnaire consisted of 30 questions, 24 of which were closed and 6 open. To apply the questionnaire, the consumers were selected randomly in the waiting room of the RHP San Miguel de Azapa. All participants were asked to partake at will and signed informed consent forms to indicate their participation. Participants were not provided with any type of definition or information about organic food products, so as to report their understanding of such products without any outside influence.

The interview with the organic farmer took place on the $15^{\text {th }}$ of May, 2014. The interview with the nutritionist took place at the RHP San Miguel of Azapa on the same date.

\section{Analysis}

The data collected in the surveys were organized with Excel $^{\mathrm{TM}}$, and the interviews were transcribed into a Word ${ }^{\mathrm{TM}}$ document. The responses to the closed questions were classified into graphs and tables. The investigator looked for similarities among the open questions to analyze the relationships and common themes between the two types of answers. In large part, the open questions were analyzed for common key words among the responses. When no key words existed, answers were considered unique. 


\section{Results and discussion}

$35.7 \%$ of the surveyed participants were between ages $18-24,35.7 \%$ were between ages $25-39$, and $14.2 \%$ were between ages 40-59.

$43 \%$ of the surveyed participants identified themselves as Aymara, 29\% identified as Latino, $21 \%$ as Mapuche, and $7 \%$ as other. $72 \%$ of the surveyed participants had completed secondary education, $21 \%$ had completed primary education, and $7 \%$ had completed university level coursework.

$35.7 \%$ of the surveyed participants indicated that their family eats fruits and vegetables daily, $50 \%$ indicated that their families consume fruits and vegetables 3-5 days per week, $7.1 \%$ indicated that their families consume fruits and vegetables 2-4 days per week, and $7.1 \%$ indicated that their families consume fruits and vegetables 1-3 days per week.

When asked to respond to the question, "For you, what is an organic food product?" $28.5 \%$ indicated that they did not know what an organic food product is; $21 \%$ said that it is a natural product, $21 \%$ said, "it is a product without chemicals;" and the remaining $28.5 \%$ said, "the vegetables and all that uses organic vegetable waste, the shells;" or a product that "can be recycled;" "a source of basic nutrients for the body that keep it healthy". That is to say, $79 \%$ of the surveyed participants did not respond correctly when asked about the concept of an organic food product. The results reflect confusion about the concept of organic food products. The most revealing fact is that more than two thirds of the surveyed participants did not respond with the correct definition of an organic product, with the exception of the organic olive farmer. $21 \%$ of the surveyed participants responded with a close, yet incorrect definition; these responses still do not express a clear understanding of what is an organic product. This demonstrates that the people of Azapa Valley do not have access to clear information about organic food products, and therefore cannot confirm that they actually do consume organic products.

The definition reported from the nutritionist reflects the same tendency, as he could not accurately define the concept under investigation. According to the information collected in the study, there was no relationship between socioeconomic level, education level or other demographic parameters with the level of understanding of the concept of organic food products.

\section{Literature Cited}

Jensen, A.

2012. Fact Sheet-Agro Industry \& Food Technology in Chile: World food power with economic growth in a healthy business environment. Santiago: The Danish Embassy. Available in: http://chile.um.dk/da/ /media/Chile/Final\%20 Fact $\% 20$ sheet $\% 20 \% 20$ Agro $\% 20$ Industry $\% 20 \% 20$ Food $\% 20$ Technology.pdf. Consulted: 31, agosto 2014.

Kilcher, L., \& Willer, H.

2012. The World of Organic Agriculture - Statistics and Emerging trends 2012. Bonn, Germany: Research Institute of Organic Agriculture (FiBL), Frick, and International Federation of Organic Agriculture Movements (IFOAM). Available in: https://www.fibl.org/fileadmin/documents/shop/1546-organicworld-2011.pdf. Consulted: 31, agosto 2014.
ODEPA.

2011. ¿Qué, cuánto y dónde se produce orgánicamente en Chile? Santiago: Oficina de Estudios y Políticas Agrarias (ODEPA), Ministerio de Agricultura. Consultado en: http://www.odepa. gob.cl/odepaweb/servicios-informacion/Mercados/mar-11.pdf Saavedra, A. y L. Tapia.

2009. Evaluación de las estrategias de producción de tomate (Lycopersicon esculentum Mill.) fuera de estación para la agricultura de la provincia de Arica, Chile, entre los años 1995-2005. Idesia, 27(2): 91-96.

Torres, A. y E. Acevedo.

2008. El problema de salinidad en los recursos suelo y agua que afectan el riego en los valles de Lluta y Azapa en el norte de Chile. Idesia, 26(3): 31-44. 
